\title{
Post-Meiotic DNA Damage and Response in Male Germ Cells
}

\author{
Frédéric Leduc et al.* \\ Department of Biochemistry, Faculty of Medicine and Health Sciences \\ Université de Sherbrooke \\ Canada
}

\section{Introduction}

Spermatids are haploid cells that differentiate into spermatozoa and may be considered as an interesting model of DNA damage response and repair. Key features, such a unique set of chromosomes, radioresistance to apoptosis, the presence of known end-joining DNA repair pathways and an underlying prerogative to limit the transmission of any mutation to the next generation, make them a unique cell type to provide new insights on similar pathways in somatic cells. Although DNA damage signaling and repair mechanisms have been extensively studied during meiosis, the contribution of post-meiotic germ cells to the genetic integrity of the male gamete have been overlooked. In this chapter we present clear evidences that the haploid phase of spermatogenesis, termed spermiogenesis, may represent an even greater challenge for the maintenance of the genetic integrity of the male gamete. Since transient DNA strand breaks are intrinsic to the differentiation program of spermatids (Leduc et al., 2008a; Marcon and Boissonneault, 2004), a better understanding of DNA repair pathways involved may shed some light on their potential contribution to male-driven de novo mutations and eventually to some unresolved cases of male infertility. This chapter will mainly focus on DNA breaks occurring in the post-meiotic phase of the spermatogenesis and how germ cells deal with it.

\section{Spermatogenesis}

In most mammals, testes are found in the scrotum and are maintained at lower temperature $\left(2-8^{\circ} \mathrm{C}\right)$ than the core body (Harrison and Weiner, 1949; Setchell, 1998). In fact, spermatogenesis is known to work better at lower temperature and it was shown that fertility declines with scrotal hyperthermia. For example, higher scrotal temperature due to fever or lifestyle correlates with decreased semen quality in humans (reviewed in Jung and Schuppe, 2007).

To support germ cells in their development, Sertoli cells are located at the basal lamina, throughout the seminiferous tubules (Russell, 1990). They provide nutrients and essential

\footnotetext{
* Geneviève Acteau, Marie-Chantal Grégoire, Olivier Simard, Jessica Leroux, Audrey Carrier-Leclerc, Mélina Arguin and Guylain Boissonneault Department of biochemistry, Faculty of medicine and health sciences, Université de Sherbrooke, Canada
} 
molecules to the differentiating germ cells and regulate the seminiferous tubular fluid (Griswold, 1998; Rato et al., 2010). The Sertoli cells are interconnected by different junctions, creating a unique barrier between surrounding blood vessels and differentiating germ cells that is known as the "blood-testis barrier" (Cheng and Mruk, 2002; Dym and Fawcett, 1970; Setchell, 1969; Vogl et al., 2008). This barrier restricts molecules to enter or exit the adluminal compartment, creating a microenvironment with diverse transporters and preventing immunological response against germ cells (reviewed in Mital et al., 2011).

Spermatogenesis is the cellular differentiation pathway leading to the production of male gametes. This process takes place in seminiferous tubules in the testis, which is a unique environment regulated by follicle-stimulating and luteinizing hormones, secreted by the pituitary gland (Russell, 1990). From birth to puberty, seminiferous tubules are composed of spermatogonia, the precursor stem cell of the germinal cells, and Sertoli cells. At the onset of puberty, spermatogonia undergo mitosis and commit to the differentiation pathway leading to male germ cells. As the germ cells differentiate, they migrate towards the lumen of the tubule, creating an organized stratified structure. Spermatogenesis can be divided in two phases, spermatocytogenesis and spermiogenesis.

Spermatocytogenesis is the process by which a spermatogonium differentiates into primary spermatocytes, which duplicate their DNA to undergo meiosis and become haploid spermatids. This meiotic division is important to create genetic variations by meiotic crossovers and random segregation of parental chromosomes. Spermiogenesis is characterized by the radical metamorphosis of the haploid spermatid into spermatozoa, requiring the reorganization of their organelles. The acrosome, a cap-like structure needed for enzymatic digestion of the oocyte outer membrane, is formed from the Golgi apparatus. At the opposite nuclear pole, the flagellum begins to grow from the centrioles and mitochondria groups at the mid-piece of the emerging flagellum to produce the required energy for its later motion. Finally, the spermatid is stripped of most of its cytoplasm and ultimately released in the lumen of the seminiferous tubule. Most interestingly, the nucleus of spermatids is also remodeled and condensed to protect the paternal genome as well as providing a more hydrodynamic shape. However, this nuclear reorganization is characterized by transient DNA strand breaks that may be necessary to relieve the torsional stress as outlined below.

\subsection{Chromatin remodeling process}

Through the chromatin remodeling process of spermatids, the paternal genome is condensed tenfold compared to somatic cells, forming a nucleus with an hydrodynamicshape (Balhorn et al., 1984). To achieve such a high degree of compaction, chromatin must first rely on a set of abundant transition proteins (TPs) subsequently replaced by the protamines (PRMs) (Balhorn et al., 1984; Braun, 2001). The arginine-rich PRMs bind DNA and neutralize the phosphodiester backbone of the double helix (Balhorn, 1982), allowing for a tight compaction of the DNA into torroids (Ward, 1993). Although the onset of chromatin remodeling is poorly understood, incorporation of testis-specific histone variants (Churikov et al., 2004; Govin et al., 2007; Lu et al., 2009; Martianov et al., 2005; Yan et al., 2003) and regulated post-translational modifications of histones, such as acetylation (Christensen et al., 1984; Grimes and Henderson, 1984; Marcon and Boissonneault, 2004; Meistrich et al., 1992), ubiquitination (Baarends et al., 1999; Chen et al., 1998), methylation (Godmann et al., 2007; van der Heijden et al., 2006) and phosphorylation (Blanco-Rodríguez, 
2009; Krishnamoorthy et al., 2006; Leduc et al., 2008a; Meyer-Ficca et al., 2005) are known to initiate and participate in the exchange from histones to the more basic proteins such as TPs and PRMs during the transition from the round to the elongated spermatids. These modifications are known to modulate the affinity of histones for DNA, but also the affinity of other proteins for histones, such as chromatin remodelers, DNA repair proteins or the transcription machinery. After spermiation, this unique protamine-based chromatin is further stabilized by the creation of intraprotamine disulfide bonds during the transit through the epididymis (Golan et al., 1996). Therefore, protamination provides both chemical and mechanical protection to the male haploid genome. Interestingly, protamination of the male genome is not complete and varies across species. In the mouse spermatozoon, about $1-2 \%$ of the genome remains organized by histones (Balhorn et al., 1977), whereas up to $15 \%$ of histones are still found in humans spermatozoa (Gatewood et al., 1990; Gusse et al., 1986; Tanphaichitr et al., 1978). This observation lead to hypothesize that these nucleosomes could serve as epigenetic markers for embryonic development (Arpanahi et al., 2009; Zalenskaya et al., 2000) (for a more detailed review on the sperm chromatin organization, see Johnson et al., 2011)

\section{Nature of endogenous DNA damages during spermiogenesis}

\subsection{Single strand damage and repair}

Depending on the type of damage, specific pathways achieve single strand damage repair (see Table 1). Mispaired DNA bases that primarily arise during replication are corrected by mismatch repair (MMR), while small chemical alterations of DNA bases such as alkylation, deamination and oxidative damage are repaired by base excision repair (BER) (Mukherjee et al., 2010; Robertson et al., 2009). More complex lesions such as those induced by UV (pyrimidine dimers and helix-distorting lesions) are corrected by nucleotide excision repair (NER), a multistep pathway that involves more than 30 proteins (Hoeijmakers, 2009; Nouspikel, 2009). DNA nicks are repaired by single-strand break repair (SSBR). These DNA repair pathways are known to be present and active during spermiogenesis (Olsen et al., 2001; Schultz et al., 2003). To our knowledge, single-strand damages do not present a major threat to spermatids. With the exception of exposures to toxicant that could challenge these pathways, in normal conditions, single-strand DNA damage during spermiogenesis is likely attributed to the massive transcription that is taking place at these steps and is efficiently resolved by spermatids (Olsen et al., 2001). DNA double-strand breaks were reported as part of the normal differentiation program of spermatids during spermiogenesis which may represent an important source of genetic instability and therefore we will focus on these pathways.

\subsection{Double-strand breaks in spermatids \\ 3.2.1 Possible origin of DNA breaks}

Several hypotheses have been formulated to elucidate the origin and role of DNA strand breaks in spermatids. Sakkas and colleagues suggested that "abortive apoptosis" may be the cause since abnormal human spermatozoa presented some apoptotic-like features (Sakkas et al., 1999). Further investigation led to the demonstration that other biomarkers of apoptosis in sperm cells were present such as BCL-X, TP53, caspases, in addition to diverse structural defects (Baccetti et al., 1997; Donnelly et al., 2000; Gandini et al., 2000; Sakkas et al., 2002; Weng et al., 2002). Due to technical limitations at the time, DNA breaks were only observed 


\begin{tabular}{|c|c|c|c|}
\hline \multicolumn{2}{|c|}{ DNA repair pathways } & DNA damages & Implicated proteins \\
\hline \multicolumn{2}{|c|}{ Mismatch repair (MMR) } & Mispaired DNA bases & $\begin{array}{l}\text { MSH1-6, MLH1, MLH3, } \\
\text { PMS1, PMS2, EXO1, RPA, } \\
\text { PCNA, RFC }\end{array}$ \\
\hline \multirow{2}{*}{$\begin{array}{l}\text { Base excision repair } \\
\text { (BER) }\end{array}$} & Short-patch & \multirow{2}{*}{$\begin{array}{l}\text { Small DNA bases } \\
\text { chemical alteration } \\
\text { arising from } \\
\text { alkylation, } \\
\text { deamination and } \\
\text { oxidative damage }\end{array}$} & $\begin{array}{l}\text { UNG, APEX1, POL } \beta \text {, } \\
\text { XRCC1, LIG3 }\end{array}$ \\
\hline & Long-patch & & $\begin{array}{l}\text { UNG, APEX1, POL } \beta \text { / } \delta, \\
\text { FEN1, PCNA, LIG1 }\end{array}$ \\
\hline $\begin{array}{l}\text { Nucleotide excision } \\
\text { repair (NER) }\end{array}$ & $\begin{array}{l}\text { Transcription } \\
\text {-coupled or } \\
\text { not }\end{array}$ & Pyrimidine dimer & $\begin{array}{c}\text { XPC complex, DDB } \\
\text { complex, ERCC3 (TFIIH), } \\
\text { XPA-RPA complex, ERCC5 } \\
\text { (XPG), ERCC1-ERCC4 } \\
\text { (XPF), LIG3, DNA } \\
\text { polymerase } \delta\end{array}$ \\
\hline $\begin{array}{l}\text { Single strand break } \\
\text { repair (SSBR) }\end{array}$ & $\begin{array}{l}\text { Short-patch } \\
\text { or } \\
\text { long-patch }\end{array}$ & $\begin{array}{l}\text { Single strand break } \\
\text { (SSB) }\end{array}$ & $\begin{array}{c}\text { APE1, PNKP, APTX, TDP1, } \\
\text { POL } \beta / \delta / \varepsilon, \text { PCNA, } \\
\text { XRCC1, LIG1/3, FENI, } \\
\text { PARP }\end{array}$ \\
\hline
\end{tabular}

Table 1. Summary of the single strand DNA repair pathways in mammalian cells (Ciccia and Elledge, 2010; Hoeijmakers, 2009; Martin et al., 2010; Mukherjee et al., 2010; Nouspikel, 2009; Robertson et al., 2009).

in a subset of the whole population of elongating spermatids and therefore abortive apoptosis could represent a sound explanation. However, some studies demonstrated that round spermatids are radioresistant to apoptosis and may not have the proper machinery and checkpoints to trigger such process (Ahmed et al., 2010; Oakberg and Diminno, 1960). Furthermore, our group have demonstrated that transient DNA breaks were present in the whole population of elongating spermatids of fertile mice and humans during chromatin remodeling and were therefore part of the normal differentiation program of these cells (Marcon and Boissonneault, 2004). The persistence of these breaks beyond the chromatin remodeling steps in pathological conditions may explain the presence of DNA fragmentation found in spermatozoa of infertile men (Leduc et al., 2008b).

Generation of controlled DNA breaks either single- or double-stranded may be important to relieve the torsional stress induced by the withdrawal of histones (Boissonneault, 2002). The simple mechanical stress resulting from the accumulation of free supercoils could induce non-B DNA structures and possibly DNA breaks as the chromatin remodeling is extensive and takes place within many differentiation steps. However, enzymatic induction of DNA strand breaks is more likely, as their free ends can be end-labeled with polymerases that require a $3^{\prime} \mathrm{OH}$ as substrate, such as the terminal deoxynucleotidyl transferase (TdT) used in TUNEL labeling. Specific nucleases could be involved in this process, and it is not excluded that retrotransposon nucleases could play a role as they are expressed throughout 
spermatogenesis, including in the nucleus of spermatids (Branciforte and Martin, 1994; Ergün et al., 2004; Gasior et al., 2006). However, topoisomerases have long been considered likely candidates to support chromatin remodeling from bulky histone-bound chromatin to compact and transcriptionally inert protamine-bound DNA because of their ubiquitous role in chromosome dynamics during the somatic cell cycle (McPherson and Longo, 1993).

\subsubsection{Topoisomerases as candidates to supercoiling removal}

Change in DNA topology can be achieved by single-strand breaks (SSBs) generated by type I topoisomerase, which modifies the linking number in steps of one. Single-strand breaks would be considered a much smaller threat for the genome's integrity of spermatids than a DSB that could be generated by type II topoisomerases. However, chromatin remodeling in spermatids was clearly shown to be associated with an increase in type II topoisomerase (Chen and Longo, 1996; Laberge and Boissonneault, 2005; Leduc et al., 2008a; McPherson and Longo, 1992, 1993; Meyer-Ficca et al., 2011b; Roca and Mezquita, 1989). A possible link between type II topoisomerases and DNA breaks found in elongating spermatids was suggested by the elimination of DNA breaks in spermatids nuclei incubated with type II topoisomerase inhibitors such as suramin and etoposide (Laberge and Boissonneault, 2005). In mammal cells, the $\alpha$ and $\beta$ isoforms of topoisomerase share more than $80 \%$ of homology and are differentially expressed. Topoisomerase IIa (TOP2A) is mostly found in replicating cells whereas topoisomerase II $\beta$ (TOP2B) predominates in quiescent cells (Morse-Gaudio and Risley, 1994; Turley et al., 1997). Using immunofluorescence on mouse testis sections, we have observed TOP2B foci in nuclei of elongating spermatids whereas TOP2A remained undetected in these cells but highly present in spermatocytes (see Figure 1) (Leduc et al., 2008a). Detection of TOP2B in elongating spermatids is not surprising, as spermatids are non-replicative cells. Recent studies confirmed the involvement of TOP2B in elongating spermatids (Meyer-Ficca et al., 2011b) and also observed its presence further downstream of the male germ cells differentiation program as part of the nuclear matrix of sperm cells, supporting its earlier role in the chromatin remodeling of spermatids (Shaman et al., 2006).

\subsubsection{Topoisomerases and DNA repair}

Type II topoisomerase activity may be modulated by post-translational modifications, such as phosphorylation by kinases and poly (ADP-ribosyl)ation by poly (ADPribose) polymerases (PARPs), a well-known family of proteins involved in a multitude of nuclear events, such as DNA repair and chromatin remodeling. This complementary interaction between TOP2B and PARPs may be involved in numerous cellular processes. For example, TOP2B and PARP1 are known to modulate transcription in somatic cells (Ju et al., 2006). Furthermore, these proteins may be important constituents of the nuclear matrix; Zaalishvili and coworkers observed the stimulation of cleavage of nuclear matrix associated DNA loops of neuron and leukocyte nucleoids when incubated in buffer supporting topoisomerase and PARP activity (Zaalishvili et al., 2005). This stimulation was reversed by the addition of thymidine, a PARP inhibitor. The authors suggested that a PARP-modified topoisomerase II may cut efficiently but the (ADP-ribosyl)ation could inhibit the religation. Recently, Meyer-Ficca and colleagues demonstrated a possible modulation of TOP2B activity by PARP and PARG in vitro using recombinant proteins as well as in vivo during mouse spermiogenesis through the use of inhibitors and knockout mouse models (MeyerFicca et al., 2011b). According to their findings, there is a functional relationship between the DNA strand break activity of TOP2B and the DNA strand break-dependent activation of 

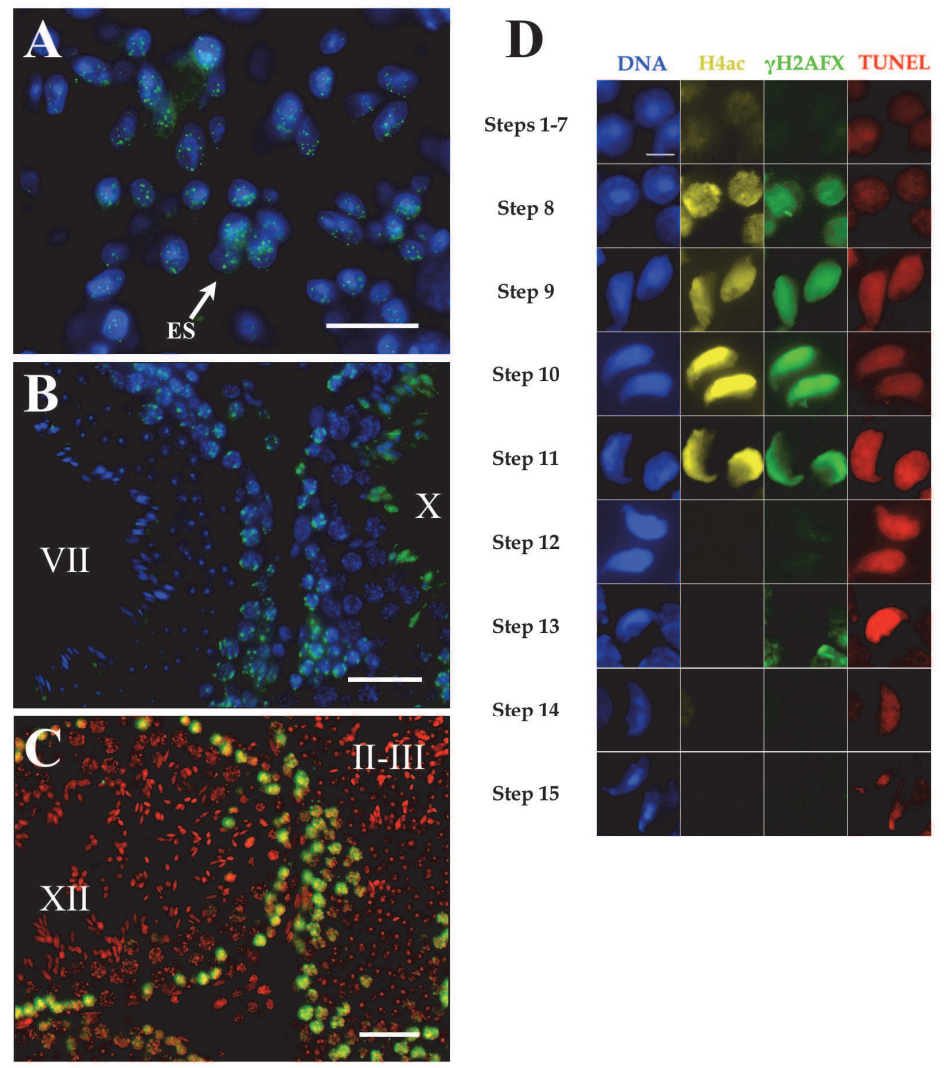

Fig. 1. Presence of type II topoisomerases, hyperacetylated histone $\mathrm{H} 4, \gamma \mathrm{H} 2 \mathrm{AFX}$ and DNA breaks during mouse spermiogenesis. (A) Overlay of TOP2B immunofluorescence (green) and DAPI nuclear staining (blue) of a stage IX tubule demonstrating the presence of TOP2B in nuclei of elongating spermatids (ES) at the onset of chromatin remodeling. (B) Overlay of TOP2B immunofluorescence (green) and DAPI (blue) nuclear staining of stages VII and X tubules. (C) Overlay of immunofluorescence of TOP2A (green) and TO-PRO3 (red) nuclear staining of stages XII and II-III demonstrating the nuclear presence of TOP2A in zygotene and pachytene spermatocytes but complete absence in spermatids. (D) Detection of hyperacetylated histone $\mathrm{H} 4$ and $\gamma \mathrm{H} 2 \mathrm{AFX}$ by immunofluorescence and DNA breaks by TUNEL during mouse spermiogenesis. DNA was counterstained by TO-PRO3. (A-C) Immunofluoresence on Bouin-fixed testis sections was done as previously described(Leduc et al., 2008a). (D) Squash preparation were done as previously described (Kotaja et al., 2004; Leduc et al., 2008a), fixed with ice-cold ethanol and processed for TUNEL and immunofluorescence. Bars $=10 \mu \mathrm{m}$ (A and B), $20 \mu \mathrm{m}(\mathrm{C})$ and $5 \mu \mathrm{m}(\mathrm{D})$.

PARP enzymes. Moreover, alteration in the PAR metabolism leads to a greater retention of histones in spermatozoa (Meyer-Ficca et al., 2011a). Whether PARP1 is involved directly in chromatin remodeling, DNA repair or combination of both in spermatids remains to be determined and will be discussed further in section 4 . 


\section{DNA damage response and DNA repair of double-strand breaks}

\subsection{DNA damage signaling pathways}

The first step following a DSB is the detection of the DNA damage by sensors (Lamarche et al., 2010). At least four independent sensors can detect DSBs: PARPs in all cases of SSBs and, to a lesser extent, DSBs, Ku70/80 in D-NHEJ, MRE11-RAD50-NBS1 (MRN) complex in all cases of DSBs and replication protein A1 (RPA) in HR (Ciccia and Elledge, 2010; Lamarche et al., 2010).

As previously stated in section 3.2.3, the presence and activity of PARP1 and PARP2 have been recently investigated during spermiogenesis of mouse and rat (Ahmed et al., 2010; Dantzer et al., 2006; Meyer-Ficca et al., 2005; Meyer-Ficca et al., 2011a; Meyer-Ficca et al., 2009; Meyer-Ficca et al., 2011b). Although the individual absence of these proteins leads only to subfertility in male, it is believed that they play a key role in the maintenance of genomic integrity of spermatids. As discussed previously, PARPs may be involved in DNA repair and signaling, in the drastic chromatin remodeling of spermatids and even in the repackaging of their genome with protamines (Quénet et al., 2009). However, the embryonic lethal phenotype of double knockout mouse prevent a better assessment of their critical role during spermiogenesis, as the absence of one can be compensated for by the other. The Ku heterodimer binds to DSB ends and is required for the non-homologous end-joining pathway (NHEJ). In addition to its role in DNA repair, Ku proteins are also required for the maintenance of telomeres and subtelomeric gene silencing (Celli et al., 2006; Lamarche et al., 2010). KU70 is present during the spermiogenesis of mouse (Goedecke et al., 1999; Hamer et al., 2003), human (Leduc et al., unpublished observations), and grasshoppers (Cabrero et al., 2007), but seems to decrease as spermiogenesis proceeds, most notably after the expulsion of histones. Although initial analyses of the implication of MRN complex as sensor in non-homologous end-joining pathways produced conflicting results (Di Virgilio and Gautier, 2005; Huang and Dynan, 2002), recent studies showed that siRNA mediated knockdown of Mre11 results in reduced end-joining efficiency in both D-NHEJ and B-NHEJ pathways (Rass et al., 2009; Xie et al., 2009) and should be considered a good candidate for DNA breaks detection and signaling in spermatids. As for Ku proteins, Mre11 is also present during spermiogenesis (Goedecke et al., 1999). Contrary to these DNA break sensor proteins, RPA may not play such an important role during spermiogenesis as spermatids, being haploid, cannot rely on HR repair processes.

The detection of DNA damage by sensors activates proteins of the phosphatidylinositol 3kinase-like protein kinase (PIKKs) family such as ATM, ATR, and DNA PKcs and members of the PARP family. These proteins post-translationnally modify key protein targets triggering a signal transduction cascades that forms the DNA damage response (DDR) (Lamarche et al., 2010). During mouse spermiogenesis, ATM and DNA PKcs are present and active (Ahmed et al., 2010; Scherthan et al., 2000). These kinases are responsible for the phosphorylation of the histone H2A variant, H2AFX, at serine $139(\gamma \mathrm{H} 2 \mathrm{AFX}$, previously referred to as $\gamma \mathrm{H} 2 \mathrm{AX}$ ), which quickly occurs after a DSB. This modification can spread up to a $2 \mathrm{Mbp}$ region flanking all DSBs (Kinner et al., 2008) and it could help the recruitment of other proteins of the DDR (Celeste et al., 2003). Within minutes following DNA damage, $\gamma \mathrm{H} 2 \mathrm{AFX}$ appears at discrete nuclear foci that dissolve after the completion of DNA repair. It remains unclear whether $\mathrm{\gamma H} 2 \mathrm{AFX}$ is replaced completely with new H2AFX histones, or simply dephosphorylated, but strong evidences suggest that the latter mechanism is 
prominent (Chowdhury et al., 2005; Rogakou et al., 1999). Therefore, the implication of $\gamma \mathrm{H} 2 \mathrm{AFX}$ in all cases of DSBs makes it a novel biomarker for DSBs detection by immunoflorescence (Mah et al., 2010; Mah et al., 2011). Upon $\gamma \mathrm{H} 2 \mathrm{AFX}$ signaling, specific pathways are recruited according to cell type or the cell cycle phase (Shrivastav et al., 2008). The presence of $\mathrm{\gamma H} 2 \mathrm{AFX}$ during spermiogenesis has been first shown in rats (Meyer-Ficca et al., 2005) and we confirmed its presence at the corresponding steps during mouse spermiogenesis (Leduc et al., 2008a) (see Figure 1). As shown in Figure 1, the presence of $\mathrm{\gamma H} 2 \mathrm{AFX}$ and hyperacetylated histone $\mathrm{H} 4$, a biomarker of chromatin remodeling coincides with the presence of TOP2B. These results confirm the previously published strong TUNEL labeling of elongating spermatids during chromatin remodeling (Laberge and Boissonneault, 2005; Marcon and Boissonneault, 2004).

Therefore, spermatids undergo multiple transient DSBs, inducing a classic DDR signaling. In addition, as seen by immunofluorescence in Figure 1, $\gamma \mathrm{H} 2 \mathrm{AFX}$ is present in all spermatids throughout chromatin remodeling as part of the normal process of maturation of spermatids. The pattern of $\gamma \mathrm{H} 2 \mathrm{AFX}$ in spermatids as seen in Figures 1 and 2 is dependent on fixation and tissue processing; ethanol fixation provides a better context for TUNEL labeling but alters nuclear distribution of proteins. Furthermore, we have also found the presence of $\gamma \mathrm{H} 2 \mathrm{AFX}$ and DNA breaks during human spermiogenesis (see Figure 2), while other groups subsequently demonstrated similar DDR signaling in grasshoppers (Cabrero et al., 2007) and even in the algae Charas vulgaris (Wojtczak et al., 2008). Moreover, the presence of DNA breaks has also been found during spermiogenesis of drosophila (Rathke et al., 2007). Altogether, these results suggest that the DDR triggered by endogenous breaks in spermatids is evolutionary conserved and could represent a new source of male-driven genetic instability in species where gametogenesis requires condensation of the genetic material.
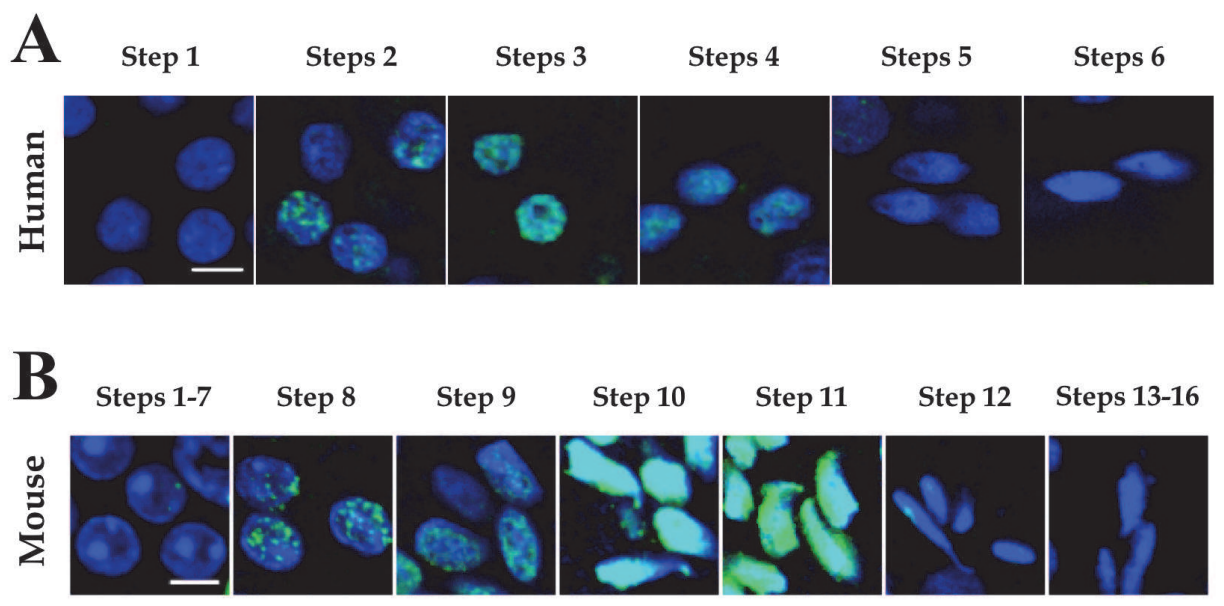

Fig. 2. Detection of $\gamma \mathrm{H} 2 \mathrm{AFX}$ during spermiogenesis of human (upper panel), and mouse (lower panel). DNA was counterstained by TO-PRO3. Bars $=5 \mu \mathrm{m}$. Immunofluoresence on paraformaldehyde-fixed testis sections was done as previously described (Leduc et al., 2008a). 


\subsection{Evidences of an active DNA repair system during spermiogenesis}

Although these DSBs are considered the most harmful genetic damage for a cell, we know from experimental data (Marcon and Boissonneault, 2004) that these breaks are repaired by the end of spermiogenesis in fertile animals. The disappearance of $\gamma \mathrm{H} 2 \mathrm{AFX}$ in mouse spermatids (step 13 to 16) shown in Figure 1 cannot be associated with completion of DNA repair or dephosphorylation as a majority of histones are expulsed from the nucleus to be replaced by PRMs. However, we obtained other evidences of an active DNA repair system at these steps by demonstrating incorporation of dNTPs in situ that is sustained through all the chromatin remodeling steps (see Figure 3) (Leduc et al., 2008a). Furthermore, as seen in Figure 1, the appearance and disappearance of TUNEL labeling is coincident with $\gamma \mathrm{H} 2 \mathrm{AFX}$ fluorescence. To confirm that the loss of TUNEL labeling was associated with DNA repair and not with the lack of penetrability of the TdT in the nuclei of condensed spermatids, we decondensed spermatids prior to TUNEL with similar results (Marcon and Boissonneault, 2004) (Acteau et al., unpublished observations). Therefore, DNA breaks are properly repaired by the end of the spermatids differentiation program. As previously stated, mammalian cells can rely on four DNA DSBs repair pathways, each of which having different degree of fidelity. As spermatids differentiate to spermatozoa with fertilizing potential, any errors due to faulty or incomplete DNA repair may be transmitted to the next generation. Severe alteration in the repair process may cause infertility or possibly be incompatible with embryonic development (Leduc et al., 2008b).

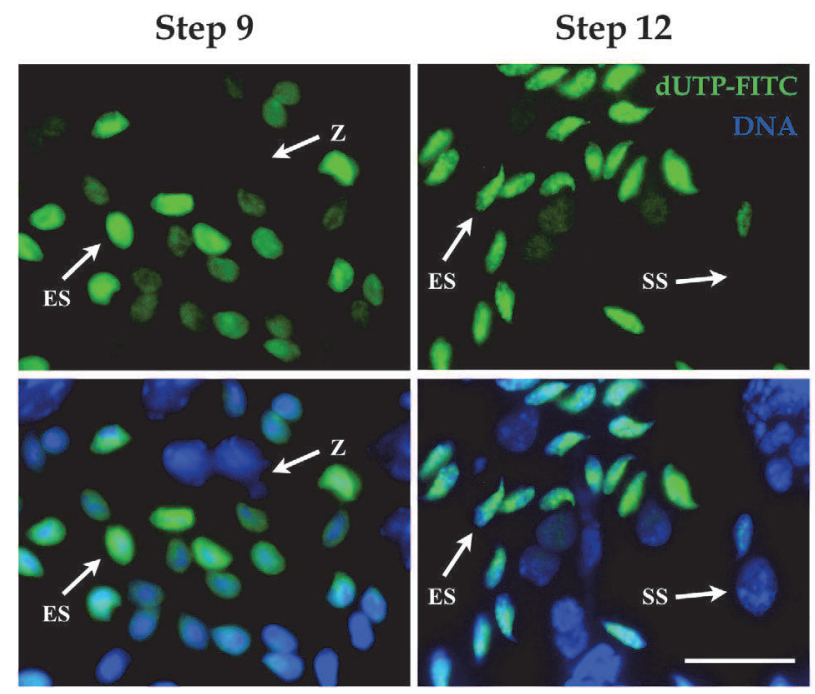

Fig. 3. In situ endogenous DNA polymerase activity assay (Leduc et al., 2008a) on squash preparation of stage IX and XII tubules. DNA was counterstained by DAPI. Bar $=10 \mu \mathrm{m}$

\subsection{Towards identification of DNA repair pathways}

Double-strand breaks are processed either by homologous recombination, single-strand annealing (SSA) or non-homologous end-joining (Caldecott, 2008). Two types of NHEJ are available to mammalian cells: the pathway that is dependent of DNA PKcs (referred to as D- 
NHEJ) and the alternative (or "back-up") pathway (referred to as B-NHEJ), which is also known as microhomology-mediated end-joining (MMEJ) (Ciccia and Elledge, 2010; West, 2003). Therefore, we will discuss known somatic DNA repair pathways and their potential role in spermatids when supported by published data.

\subsubsection{Homologous recombination and single-strand annealing}

Given the haploid character spermatids, HR could not take place as sister chromatids or homologous chromosomes are not available for recombination. Considering that HR precisely restores the genomic sequence of the broken DNA ends by utilizing sister chromatids as template for DNA repair, HR usually occurs in late S2 and G phase of the cycle in mammals (Kass and Jasin, 2010), whereas spermatids are considered to be in a G1like phase (Ahmed et al., 2010). Upon resection at DNA breaks by the MRN complex, two different pathways are usually possible: HR or SSA (Wold, 1997). The SSA pathway could use repetitive DNA sequences to promote the DNA repair of DSBs in spermatids (Hartlerode and Scully, 2009; Motycka et al., 2004). This pathway is known to introduce errors such as deletions, insertions and even be a substrate for chromosomal translocations (Griffin and Thacker, 2004). There is currently no evidence that spermatids use SSA rather than NHEJ to repair DSBs, but some key proteins of this pathway, although also part of the NER pathway (see Table 1 and Table 2), are present during spermiogenesis including ERCC1 (Hsia et al., 2003; Paul et al., 2007) as well as XPF (Shannon, 1999).

\begin{tabular}{||c|c|c||}
\hline \hline DNA repair pathways & Implicated proteins & Typical error \\
\hline \hline $\begin{array}{c}\text { Homologous } \\
\text { recombination (HR) }\end{array}$ & $\begin{array}{c}\text { BRCA1/2, Rad51, } \\
\text { XRCC2, LIG1, RPA }\end{array}$ & Error free \\
\hline \hline $\begin{array}{c}\text { Single strand annealing } \\
\text { (SSA) }\end{array}$ & $\begin{array}{c}\text { ERCC1, ERCC4 (XPF), } \\
\text { Rad52 }\end{array}$ & $\begin{array}{c}\text { Indels }(++) \\
\text { Chromosomal translocation } \\
(++)\end{array}$ \\
\hline $\begin{array}{c}\text { Non-homologous end- } \\
\text { joining DNA PK dependant } \\
\text { (D-NHEJ) }\end{array}$ & $\begin{array}{c}\text { ARTEMIS, XRCC4, LIG4, } \\
\text { XLF (NHEJ1) }\end{array}$ & $\begin{array}{c}\text { Chromosomal translocation }(+) \\
(+)\end{array}$ \\
\hline \hline $\begin{array}{c}\text { Alternative non- } \\
\text { homologous end joining } \\
\text { (B-NHEJ) }\end{array}$ & PARP, XRCC1, LIG3 & $\begin{array}{c}\text { Indels }(+) \\
(+)\end{array}$ \\
\hline \hline
\end{tabular}

Table 2. DNA double-strand break repair pathways and their typical error. (+) Occasional, $(++)$ frequent (Ciccia and Elledge, 2010; Griffin and Thacker, 2004).

\subsubsection{Non-homologous end joining}

Besides SSA, B-NHEJ and D-NHEJ are potentially available for the repair of double-strand breaks during spermiogenesis (Leduc et al., 2008a; Leduc et al., 2008b). In somatic cells, NHEJ pathways promote the religation of DSBs, introducing small insertions and deletions. NHEJ pathways operates throughout the cell cycle but are most active during G1 phase 
because HR cannot proceed during that time (Daley et al., 2005). Spermatids provide a similar cellular context as G1 phase of somatic cells. However, dynamics of DNA repair by NHEJ pathways, as illustrated in irradiated round spermatids, are much slower (Ahmed et al., 2010). According to Ahmed and colleagues both pathways are present and active during mouse spermiogenesis: spermatids of SCID mice, lacking the D-NHEJ because of the absence of DNA PKcs, displayed slower repair than those from wild type mice (Ahmed et al., 2010). Further studies on the end-joining pathways in elongating spermatids will be required as these are known to be error-prone in somatic cells. This may also be the case in spermatids. Although an attenuation of the frequency of mutations may be found in the germ line (Walter et al., 1998), the chromatin remodeling in spermatids may still be the key differentiation steps where most of the new mutations repertoire is being produced for the transmission to the next generation.

\section{Possible consequences on fertility and genetic integrity}

\subsection{Incomplete DNA repair}

High level of sperm DNA fragmentation, sperm DNA damages and chromatin alterations decrease pregnancy rates in natural fertilization, intrauterine insemination and in vitro fertilization (Bungum et al., 2007; Duran, 2002; Evenson et al., 1999; Evenson and Wixon, 2006; Spano et al., 2000; Zini, 2011). Moreover, pregnancy loss following in vitro fertilization (IVF) or intracytoplasmic sperm injection (ICSI) treatments has also been attributed to poor sperm DNA integrity (Zini et al., 2008). Although sperm DNA fragmentation is more frequent in infertile men, sperm of fertile men display DNA fragmentation but to a lesser extent (Bellver et al., 2010; Brahem et al., 2011; Perrin et al., 2009; Rybar et al., 2009; Venkatesh et al., 2011; Watanabe et al., 2011). After fertilization, the oocyte can efficiently repair some paternal DNA damages (Brandriff and Pedersen, 1981; Marchetti et al., 2007), but in the case of highly damaged sperm DNA, this could exceed the DNA repair capacity of the oocyte leading to some genetic aberrations, developmental arrest or pregnancy loss.

\subsection{Faulty repair}

\section{Structural aberrations}

Chromosomal structural aberrations such as translocations, deletions and inversions, may originate from meiotic recombination involving non-allelic repeated DNA sequences (Heyer et al., 2010). However, since about $80 \%$ of chromosomal rearrangements are reported to be of paternal origin (Buwe et al., 2005; Thomas et al., 2006) and that male and female meiosis involves similar genetic mechanisms (Gu et al., 2008; Thomas et al., 2006), one can surmise that yet another process unique to male gametogenesis may be involved. We therefore hypothesize that the chromatin remodeling process in spermatids, generating transient double-strand breaks, may provide the proper context for faulty repair and induction of transgenerational polymorphism. In addition, it is tempting to speculate that, because chromatin condensation occurs, free DNA ends are brought in juxtaposition, increasing the chance of NHEJ repair involving two different chromosomes, which may lead to translocations. Interestingly, chromosomes possess their own territory within the nucleus of somatic cells and in sperm cells (Hazzouri et al., 2000; Manvelyan et al., 2008; Mudrak et al., 2005; Zalenskaya et al., 2000). Moreover, chromosomes known to have higher translocation rates have close chromosomal territories in somatic cells (Branco and Pombo, 2006; Brianna 
Caddle et al., 2007; Manoj S Gandhi and Nikiforov, 2009). Thus, chromosomes with close chromosomal territories in spermatids could be more prone to interchromosomal translocation during chromatin remodeling. In addition, the potential for the spermatidal chromatin remodeling to produce non-B DNA structure may exacerbate the propensity for spermatids to produce translocation (Hidehito Inagaki and Kurahashi, 2009; Raghavan and Lieber, 2004). Further investigation is needed on the mechanism and potential involvement of chromatin remodeling in such events.

\section{Insertions and deletions}

As outlined above, NHEJ repair pathways are known to create insertions and deletions (indels) as they use microhomology to join the two DNA ends. This type of mutations may be particularly harmful in coding sequences as it may cause codon frameshifts or alteration of mRNA splicing. Moreover, Y chromosomes microdeletions, associated with increased male infertility, may exhibit the classical signature of micro-homology based DNA repair pathways such as SSA and B-NHEJ as the deletion occurs between repetitive, often palindromic sequences (Paulo Navarro-Costa and Plancha; Yen, 1998). Although SSA is available during most of spermatogenesis, the B-NHEJ signature on the highly repetitive $Y$ chromosome may be indicative of a faulty DNA repair in spermatids as this pathway is inhibited during meiosis.

\section{Dynamic mutations}

Several diseases with dynamic mutation, characterized by the expansion over generation of a trinucleotidic repeat (TNRs), are associated with a paternal bias of expansion, such as Huntington disease (HD), spinocerebellar ataxia type 2 and 7 (Cancel et al., 1997; Stevanin et al., 1998; Zühlke et al., 1993). TNRs are microsatellites sequences in coding or non-coding region of the genome. Their stability, which is relative to the chance of adopting a secondary structure, is dependent of the nature of the sequence and the length of the TNR (Kovtun et al.; Tóth et al., 2000). The exact mechanism of TNR expansion or contraction is still not clear. However, studies show strong evidences that TNR expansion in the huntingtin gene occurs during spermiogenesis; in a transgenic mouse model carrying the mutated human gene, an increased length of the CAG repetition was observed in mature spermatozoa but not in early haploid spermatids and other tissues. Kovtun and McMurray also demonstrated the involvement of MSH2, a protein involved in the gap repair and mismatch repair pathways, as this expansion was absent in HD mice MSH2-/- (Albin and Tagle, 1995; Kovtun and McMurray, 2001). The remodeling chromatin of spermatids may promote secondary structure formation at TNRs, providing an ideal context for such mutations.

\section{Conclusion}

The chromatin remodeling in spermatids involves transient DNA-strand breaks. Our group has generated evidences that a significant number of double-strand breaks are generated. These DSBs seemingly trigger a damage response as H2AFX is phosphorylated and a DNA repair pathway yet to be identified. As a result, no such DSBs are found in the mature sperm unless a pathological condition prevails. The non-templated DNA repair of these transient DSBs are expected to introduce small mutations likely distributed randomly across the haploid genome although their distribution remains to be established. Meiosis is well known to produce new combination of alleles but is not a primary driver of sequence divergence (Noor, 2008). Potential new gene function must arise through point mutations or 
indels and the present review suggests chromatin remodeling of spermatids as an appropriate context for such induction of new polymorphism and possible translocations. Although the frequency of mutation may be lower in germ cells than in somatic cells (Walter et al., 1998), we hypothesize that most of the new mutations generated during spermatogenesis may be through the process of endogenous strand breaks and repair during spermiogenesis. Owing to the $1 \%$ chance for a random mutation to occur within genes due to exonic representation in the genome, most mutations are expected to be silent but, if within coding sequences, potential alteration of gene function may be transmitted. In summary, repair of the endogenous DSBs in spermatids may represent a new male-driven source of genetic variation.

\section{References}

Ahmed, E.A., de Boer, P., Philippens, M.E.P., Kal, H.B., and de Rooij, D.G. (2010). Parp1XRCC1 and the repair of DNA double strand breaks in mouse round spermatids. Mutation Research 683, 84-90.

Albin, R.L., and Tagle, D.A. (1995). Genetics and molecular biology of Huntington's disease. Trends in Neurosciences 18, 11-14.

Arpanahi, A., Brinkworth, M., Iles, D., Krawetz, S., Paradowska, A., Platts, A., Saida, M., Steger, K., Tedder, P., and Miller, D. (2009). Endonuclease-sensitive regions of human spermatozoal chromatin are highly enriched in promoter and CTCF binding sequences. Genome Res.

Baarends, W., Hoogerbrugge, J., Roest, H., Ooms, M., Vreeburg, J., Hoeijmakers, J., and Grootegoed, J. (1999). Histone ubiquitination and chromatin remodeling in mouse spermatogenesis. Dev Biol 207, 322-333.

Baccetti, B., Strehler, E., Capitani, S., Collodel, G., De Santo, M., Moretti, E., Piomboni, P., Wiedeman, R., and Sterzik, K. (1997). The effect of follicle stimulating hormone therapy on human sperm structure. Hum Reprod 12, 1955-1968.

Balhorn, R. (1982). A model for the structure of chromatin in mammalian sperm. J Cell Biol 93, 298-305.

Balhorn, R., Gledhill, B.L., and Wyrobek, A.J. (1977). Mouse sperm chromatin proteins: quantitative isolation and partial characterization. Biochemistry 16, 4074-4080.

Balhorn, R., Weston, S., Thomas, C., and Wyrobek, A. (1984). DNA packaging in mouse spermatids. Synthesis of protamine variants and four transition proteins. Exp Cell Res 150, 298-308.

Bellver, J., Meseguer, M., Muriel, L., García-Herrero, S., Barreto, M.A.M., Garda, A.L., Remohí, J., Pellicer, A., and Garrido, N. (2010). Y chromosome microdeletions, sperm DNA fragmentation and sperm oxidative stress as causes of recurrent spontaneous abortion of unknown etiology. Human Reproduction 25, 1713-1721.

Blanco-Rodríguez, J. (2009). gammaH2AX marks the main events of the spermatogenic process. Microsc Res Tech.

Boissonneault, G. (2002). Chromatin remodeling during spermiogenesis: a possible role for the transition proteins in DNA strand break repair. FEBS Lett 514, 111-114.

Brahem, S., Mehdi, M., Elghezal, H., and Saad, A. (2011). Analysis of Sperm Aneuploidies and DNA Fragmentation in Patients With Globozoospermia or With Abnormal Acrosomes. Urology. 
Branciforte, D., and Martin, S.L. (1994). Developmental and cell type specificity of LINE-1 expression in mouse testis: implications for transposition. Mol Cell Biol 14, 25842592.

Branco, M.R., and Pombo, A. (2006). Intermingling of Chromosome Territories in Interphase Suggests Role in Translocations and Transcription-Dependent Associations. PLoS biology 4, e138.

Brandriff, B., and Pedersen, R. (1981). Repair of the ultraviolet-irradiated male genome in fertilized mouse eggs. Science 211, 1431-1433.

Braun, R.E. (2001). Packaging paternal chromosomes with protamine. Nat Genet 28, 10-12.

Brianna Caddle, L., Grant, J.L., Szatkiewicz, J., Hase, J., Shirley, B.-J., Bewersdorf, J., Cremer, C., Arneodo, A., Khalil, A., and Mills, K.D. (2007). Chromosome neighborhood composition determines translocation outcomes after exposure to high-dose radiation in primary cells. Chromosome research 15, 1061-1073.

Bungum, M., Humaidan, P., Axmon, A., Spano, M., Bungum, L., Erenpreiss, J., and Giwercman, A. (2007). Sperm DNA integrity assessment in prediction of assisted reproduction technology outcome. Human reproduction 22, 174-179.

Buwe, A., Guttenbach, M., and Schmid, M. (2005). Effect of paternal age on the frequency of cytogenetic abnormalities in human spermatozoa. Cytogenet Gen Res 111, 213-228.

Cabrero, J., Palomino-Morales, R.J., and Camacho, J.P.M. (2007). The DNA-repair Ku70 protein is located in the nucleus and tail of elongating spermatids in grasshoppers. Chromosome Res 15, 1093-1100.

Caldecott, K.W. (2008). Single-strand break repair and genetic disease. Nature Reviews Genetics 9, 619-631.

Cancel, G., Dürr, A., Didierjean, O., Imbert, G., Bürk, K., Lezin, A., Belal, S., Benomar, A., Abada-Bendib, M., Vial, C., et al. (1997). Molecular and clinical correlations in spinocerebellar ataxia 2: a study of 32 families. Human Molecular Genetics 6, 709715.

Celeste, A., Fernandez-Capetillo, O., Kruhlak, M.J., Pilch, D.R., Staudt, D.W., Lee, A., Bonner, R.F., Bonner, W.M., and Nussenzweig, A. (2003). Histone H2AX phosphorylation is dispensable for the initial recognition of DNA breaks. Nature Cell Biology 5, 675-679.

Celli, G.B., Denchi, E.L., and de Lange, T. (2006). Ku70 stimulates fusion of dysfunctional telomeres yet protects chromosome ends from homologous recombination. Nat Cell Biol 8, 885-890.

Chen, H., Sun, J., Zhang, Y., Davie, J., and Meistrich, M. (1998). Ubiquitination of histone H3 in elongating spermatids of rat testes. J Biol Chem 273, 13165-13169.

Chen, J., and Longo, F. (1996). Expression and localization of DNA topoisomerase II during rat spermatogenesis. Mol Reprod Dev 45, 61-71.

Cheng, C.Y., and Mruk, D.D. (2002). Cell junction dynamics in the testis: Sertoli-germ cell interactions and male contraceptive development. Physiol rev 82, 825-874.

Chowdhury, D., Keogh, M.-C., Ishii, H., Peterson, C.L., Buratowski, S., and Lieberman, J. (2005). gamma-H2AX dephosphorylation by protein phosphatase 2A facilitates DNA double-strand break repair. Molecular cell 20, 801-809.

Christensen, M., Rattner, J., and Dixon, G. (1984). Hyperacetylation of histone H4 promotes chromatin decondensation prior to histone replacement by protamines during spermatogenesis in rainbow trout. Nucleic Acids Res 12, 4575-4592. 
Churikov, D., Siino, J., Svetlova, M., Zhang, K., Gineitis, A., Morton Bradbury, E., and Zalensky, A. (2004). Novel human testis-specific histone H2B encoded by the interrupted gene on the X chromosome. Genomics 84, 745-756.

Ciccia, A., and Elledge, S.J. (2010). The DNA Damage Response: Making It Safe to Play with Knives. Molecular cell 40, 179-204.

Daley, J.M., Laan, R.L.V., Suresh, A., and Wilson, T.E. (2005). DNA joint dependence of pol $X$ family polymerase action in nonhomologous end joining. The Journal of biological chemistry 280, 29030-29037.

Dantzer, F., Mark, M., Quenet, D., Scherthan, H., Huber, A., Liebe, B., Monaco, L., Chicheportiche, A., Sassone-Corsi, P., de Murcia, G., et al. (2006). Poly(ADP-ribose) polymerase-2 contributes to the fidelity of male meiosis I and spermiogenesis. Proc Natl Acad Sci USA 103, 14854-14859.

Di Virgilio, M., and Gautier, J. (2005). Repair of double-strand breaks by nonhomologous end joining in the absence of Mre11. The Journal of cell biology 171, 765-771.

Donnelly, E.T., O'Connell, M., McClure, N., and Lewis, S.E. (2000). Differences in nuclear DNA fragmentation and mitochondrial integrity of semen and prepared human spermatozoa. Hum Reprod 15, 1552-1561.

Duran, E.H. (2002). Sperm DNA quality predicts intrauterine insemination outcome: a prospective cohort study. Human Reproduction 17, 3122-3128.

Dym, M., and Fawcett, D.W. (1970). The blood-testis barrier in the rat and the physiological compartmentation of the seminiferous epithelium. Biol Reprod 3, 308-326.

Ergün, S., Buschmann, C., Heukeshoven, J., Dammann, K., Schnieders, F., Lauke, H., Chalajour, F., Kilic, N., Strätling, W.H., and Schumann, G.G. (2004). Cell typespecific expression of LINE-1 open reading frames 1 and 2 in fetal and adult human tissues. J Biol Chem 279, 27753-27763.

Evenson, D., Jost, L., Marshall, D., Zinaman, M., Clegg, E., Purvis, K., de Angelis, P., and Claussen, O. (1999). Utility of the sperm chromatin structure assay as a diagnostic and prognostic tool in the human fertility clinic. Hum Reprod 14, 1039-1049.

Evenson, D., and Wixon, R. (2006). Clinical aspects of sperm DNA fragmentation detection and male infertility. Theriogenology 65, 979-991.

Gandini, L., Lombardo, F., Paoli, D., Caponecchia, L., Familiari, G., Verlengia, C., Dondero, F., and Lenzi, A. (2000). Study of apoptotic DNA fragmentation in human spermatozoa. Hum Reprod 15, 830-839.

Gasior, S.L., Wakeman, T.P., Xu, B., and Deininger, P.L. (2006). The human LINE-1 retrotransposon creates DNA double-strand breaks. J Mol Biol 357, 1383-1393.

Gatewood, J.M., Cook, G.R., Balhorn, R., Schmid, C.W., and Bradbury, E.M. (1990). Isolation of four core histones from human sperm chromatin representing a minor subset of somatic histones. J Biol Chem 265, 20662-20666.

Godmann, Auger, Ferraroni-Aguiar, Sauro, D., Sette, Behr, and Kimmins (2007). Dynamic Regulation of Histone H3 Methylation at Lysine 4 in Mammalian Spermatogenesis. Biol Reprod.

Goedecke, W., Eijpe, M., Offenberg, H., van Aalderen, M., and Heyting, C. (1999). Mre11 and Ku70 interact in somatic cells, but are differentially expressed in early meiosis. Nat Genet 23, 194-198. 
Golan, R., Cooper, T.G., Oschry, Y., Oberpenning, F., Schulze, H., Shochat, L., and Lewin, L.M. (1996). Changes in chromatin condensation of human spermatozoa during epididymal transit as determined by flow cytometry. Hum Reprod 11, 1457-1462.

Govin, J., Escoffier, E., Rousseaux, S., Kuhn, L., Ferro, M., Thévenon, J., Catena, R., Davidson, I., Garin, J., Khochbin, S., et al. (2007). Pericentric heterochromatin reprogramming by new histone variants during mouse spermiogenesis. J Cell Biol 176, 283-294.

Griffin, C.S., and Thacker, J. (2004). The role of homologous recombination repair in the formation of chromosome aberrations. Cytogenet Genome Res 104, 21-27.

Grimes, S., and Henderson, N. (1984). Hyperacetylation of histone H4 in rat testis spermatids. Exp Cell Res 152, 91-97.

Griswold, M.D. (1998). The central role of Sertoli cells in spermatogenesis. Seminars in cell \&amp; developmental biology 9, 411-416.

Gu, W., Zhang, F., and Lupski, J. (2008). Mechanisms for human genomic rearrangements. Patho Genetics 1, 4.

Gusse, M., Sautière, P., Bélaiche, D., Martinage, A., Roux, C., Dadoune, J.P., and Chevaillier, P. (1986). Purification and characterization of nuclear basic proteins of human sperm. Biochim Biophys Acta 884, 124-134.

Hamer, G., Roepers-Gajadien, H.L., van Duyn-Goedhart, A., Gademan, I.S., Kal, H.B., van Buul, P.P.W., Ashley, T., and de Rooij, D.G. (2003). Function of DNA-protein kinase catalytic subunit during the early meiotic prophase without $\mathrm{Ku} 70$ and $\mathrm{Ku} 86$. Biol Reprod 68, 717-721.

Harrison, R.G., and Weiner, J.S. (1949). Vascular patterns of the mammalian testis and their functional significance. The Journal of experimental biology 26, 304-316, $302 \mathrm{pl}$.

Hartlerode, A.J., and Scully, R. (2009). Mechanisms of double-strand break repair in somatic mammalian cells. The Biochemical journal 423, 157-168.

Hazzouri, M., Pivot-Pajot, C., Faure, A., Usson, Y., Pelletier, R., Sele, B., Khochbin, S., and Rousseaux, S. (2000). Regulated hyperacetylation of core histones during mouse spermatogenesis: involvement of histone deacetylases. Eur J Cell Biol 79, 950-960.

Heyer, W.-D., Ehmsen, K.T., and Liu, J. (2010). Regulation of homologous recombination in eukaryotes. Annual review of genetics 44, 113-139.

Inagaki H, Ohye T, Kogo H, Kato T, Bolor H, Taniguchi M, Shaikh TH, Emanuel BS and Kurahashi H (2009). Chromosomal instability mediated by non-B DNA: Cruciform conformation and not DNA sequence is responsible for recurrent translocation in humans. Genome research 19, 191.

Hoeijmakers, J.H.J. (2009). DNA damage, aging, and cancer. The New England journal of medicine 361, 1475-1485.

Hsia, K., Millar, M., King, S., Selfridge, J., Redhead, N., Melton, D., and Saunders, P. (2003). DNA repair gene Ercc1 is essential for normal spermatogenesis and oogenesis and for functional integrity of germ cell DNA in the mouse. Development 130, 369-378.

Huang, J., and Dynan, W.S. (2002). Reconstitution of the mammalian DNA double-strand break end-joining reaction reveals a requirement for an Mre11/Rad50/NBS1containing fraction. Nucleic acids research 30, 667-674.

Johnson, G.D., Lalancette, C., Linnemann, A.K., Leduc, F., Boissonneault, G., and Krawetz, S.A. (2011). The sperm nucleus: chromatin, RNA, and the nuclear matrix. Reproduction 141, 21-36. 
Ju, B., Lunyak, V., Perissi, V., Garcia-Bassets, I., Rose, D., Glass, C., and Rosenfeld, M. (2006). A topoisomerase Ilbeta-mediated dsDNA break required for regulated transcription. Science 312, 1798-1802.

Jung, A., and Schuppe, H.-C. (2007). Influence of genital heat stress on semen quality in humans. Andrologia 39, 203-215.

Kass, E.M., and Jasin, M. (2010). Collaboration and competition between DNA doublestrand break repair pathways. FEBS letters 584, 3703-3708.

Kinner, A., Wu, W., Staudt, C., and Iliakis, G. (2008). Gamma-H2AX in recognition and signaling of DNA double-strand breaks in the context of chromatin. Nucleic acids research 36, 5678-5694.

Kotaja, N., Kimmins, S., Brancorsini, S., Hentsch, D., Vonesch, J., Davidson, I., Parvinen, M., and Sassone-Corsi, P. (2004). Preparation, isolation and characterization of stagespecific spermatogenic cells for cellular and molecular analysis. Nat Methods 1, 249-254.

Kovtun, I., and McMurray, C. (2001). Trinucleotide expansion in haploid germ cells by gap repair. Nat Genet 27, 407-411.

Kovtun, I.V., Goellner, G., and McMurray, C.T. Structural features of trinucleotide repeats associated with DNA expansion. Biochem Cell Biol. 79, 325-36.

Krishnamoorthy, T., Chen, X., Govin, J., Cheung, W., Dorsey, J., Schindler, K., Winter, E., Allis, C., Guacci, V., and Khochbin, S. (2006). Phosphorylation of histone H4 Ser1 regulates sporulation in yeast and is conserved in fly and mouse spermatogenesis. Genes \& development 20, 2580.

Laberge, R.-M., and Boissonneault, G. (2005). On the nature and origin of DNA strand breaks in elongating spermatids. Biol Reprod 73, 289-296.

Lamarche, B.J., Orazio, N.I., and Weitzman, M.D. (2010). The MRN complex in doublestrand break repair and telomere maintenance. FEBS letters 584, 3682-3695.

Leduc, F., Maquennehan, V., Nkoma, G.B., and Boissonneault, G. (2008a). DNA damage response during chromatin remodeling in elongating spermatids of mice. Biol Reprod 78, 324-332.

Leduc, F., Nkoma, G.B., and Boissonneault, G. (2008b). Spermiogenesis and DNA repair: a possible etiology of human infertility and genetic disorders. Syst Biol Reprod Med $54,3-10$.

Loonie D. Russell, A.P.S.H., Robert Ettlin (1990). Histological and histopathological evaluation of the testis (Cache River Press).

Lu, S., Xie, Y.M., Li, X., Luo, J., Shi, X.Q., Hong, X., Pan, Y.H., and Ma, X. (2009). Mass spectrometry analysis of dynamic post-translational modifications of TH2B during spermatogenesis. Mol Hum Reprod 15, 373-378.

Mah, L.-J., El-Osta, A., and Karagiannis, T.C. (2010). gammaH2AX: a sensitive molecular marker of DNA damage and repair. Leukemia : official journal of the Leukemia Society of America, Leukemia Research Fund, UK 24, 679-686.

Mah, L.-J., Orlowski, C., Ververis, K., Vasireddy, R.S., El-Osta, A., and Karagiannis, T.C. (2011). Evaluation of the efficacy of radiation-modifying compounds using $\gamma \mathrm{H} 2 \mathrm{AX}$ as a molecular marker of DNA double-strand breaks. Genome integrity 2, 3 .

Gandhi MS, Stringer JR, Nikiforova MN, Medvedovic M and Nikiforov YE.. (2009). Gene position within chromosome territories correlates with their involvment in distinct rearrangement types in thyroid cancer cells. Genes Chromosomes Cancer 48, 222. 
Manvelyan, M., Hunstig, F., Bhatt, S., Mrasek, K., Pellestor, F., Weise, A., Simonyan, I., Aroutiounian, R., and Liehr, T. (2008). Chromosome distribution in human sperm a 3D multicolor banding-study. Molecular cytogenetics 1, 25.

Marchetti, F., Essers, J., Kanaar, R., and Wyrobek, A.J. (2007). Disruption of maternal DNA repair increases sperm-derived chromosomal aberrations. Proc Natl Acad Sci USA 104, 17725-17729.

Marcon, L., and Boissonneault, G. (2004). Transient DNA strand breaks during mouse and human spermiogenesis new insights in stage specificity and link to chromatin remodeling. Biol Reprod 70, 910-918.

Martianov, I., Brancorsini, S., Catena, R., Gansmuller, A., Kotaja, N., Parvinen, M., SassoneCorsi, P., and Davidson, I. (2005). Polar nuclear localization of H1T2, a histone H1 variant, required for spermatid elongation and DNA condensation during spermiogenesis. Proc Natl Acad Sci USA 102, 2808-2813.

Martin, L.M., Marples, B., Coffey, M., Lawler, M., Lynch, T.H., Hollywood, D., and Marignol, L. (2010). DNA mismatch repair and the DNA damage response to ionizing radiation: making sense of apparently conflicting data. Cancer treatment reviews $36,518-527$.

McPherson, S., and Longo, F. (1992). Localization of DNase I-hypersensitive regions during rat spermatogenesis: stage-dependent patterns and unique sensitivity of elongating spermatids. Mol Reprod Dev 31, 268-279.

McPherson, S., and Longo, F. (1993). Nicking of rat spermatid and spermatozoa DNA: possible involvement of DNA topoisomerase II. Dev Biol 158, 122-130.

Meistrich, M.L., Trostle-Weige, P.K., Lin, R., Bhatnagar, Y.M., and Allis, C.D. (1992). Highly acetylated $\mathrm{H} 4$ is associated with histone displacement in rat spermatids. Mol Reprod Dev 31, 170-181.

Meyer-Ficca, M., Scherthan, H., Burkle, A., and Meyer, R. (2005). Poly(ADP-ribosyl)ation during chromatin remodeling steps in rat spermiogenesis. Chromosoma 114, 67-74.

Meyer-Ficca, M.L., Ihara, M., Lonchar, J.D., Meistrich, M.L., Austin, C.A., Min, W., Wang, Z.Q., and Meyer, R.G. (2011a). Poly(ADP-ribose) metabolism is essential for proper nucleoprotein exchange during mouse spermiogenesis. Biol Reprod 84, 218-228.

Meyer-Ficca, M.L., Lonchar, J., Credidio, C., Ihara, M., Li, Y., Wang, Z.-Q., and Meyer, R.G. (2009). Disruption of poly(ADP-ribose) homeostasis affects spermiogenesis and sperm chromatin integrity in mice. Biol Reprod 81, 46-55.

Meyer-Ficca, M.L., Lonchar, J.D., Ihara, M., Meistrich, M.L., Austin, C.A., and Meyer, R.G. (2011b). Poly(ADP-Ribose) Polymerases PARP1 and PARP2 Modulate Topoisomerase II Beta (TOP2B) Function During Chromatin Condensation in Mouse Spermiogenesis. Biology of reproduction.

Mital, P., Hinton, B.T., and Dufour, J.M. (2011). The Blood-Testis and Blood-Epididymis Barriers Are More Than Just Their Tight Junctions. Biology of reproduction.

Morse-Gaudio, M., and Risley, M.S. (1994). Topoisomerase II expression and VM-26 induction of DNA breaks during spermatogenesis in Xenopus laevis. J Cell Sci 107 (Pt 10), 2887-2898.

Motycka, T.A., Bessho, T., Post, S.M., Sung, P., and Tomkinson, A.E. (2004). Physical and functional interaction between the XPF/ERCC1 endonuclease and hRad52. The Journal of biological chemistry 279, 13634-13639. 
Mudrak, O., Tomilin, N., and Zalensky, A. (2005). Chromosome architecture in the decondensing human sperm nucleus. Journal of Cell Science 118, 4541-4550.

Mukherjee, S., Ridgeway, A.D., and Lamb, D.J. (2010). DNA mismatch repair and infertility. Current Opinion in Urology 20, 525-532.

Noor, M.A.F. (2008). Mutagenesis from Meiotic Recombination Is Not a Primary Driver of Sequence Divergence between Saccharomyces Species. Molecular biology and evolution 25, 2439-2444.

Nouspikel, T. (2009). DNA repair in mammalian cells : Nucleotide excision repair: variations on versatility. Cellular and molecular life sciences : CMLS 66, 994-1009.

Oakberg, E.F., and Diminno, R.L. (1960). X-ray sensitivity of primary spermatocytes of the mouse.int. Int J Radiat Biol 2, 196-209.

Olsen, A., Bjørtuft, H., Wiger, R., Holme, J., Seeberg, E., Bjørås, M., and Brunborg, G. (2001). Highly efficient base excision repair (BER) in human and rat male germ cells. Nucleic Acids Res 29, 1781-1790.

Paul, C., Povey, J.E., Lawrence, N.J., Selfridge, J., Melton, D.W., and Saunders, P.T.K. (2007). Deletion of Genes Implicated in Protecting the Integrity of Male Germ Cells Has Differential Effects on the Incidence of DNA Breaks and Germ Cell Loss. PLoS ONE 2, e989.

Paulo Navarro-Costa, J.G., and Plancha, C.E. The AZFc region of the Y chromosome: at the crossroads between genetic diversity and male infertility. Human Reproduction Update 16, 525.

Perrin, A., Caer, E., Oliver-Bonet, M., Navarro, J., Benet, J., Amice, V., De Braekeleer, M., and Morel, F. (2009). DNA fragmentation and meiotic segregation in sperm of carriers of a chromosomal structural abnormality. Fertility and sterility 92, 583-589.

Quénet, D., Mark, M., Govin, J., van Dorsselear, A., Schreiber, V., Khochbin, S., and Dantzer, F. (2009). Parp2 is required for the differentiation of post-meiotic germ cells: identification of a spermatid-specific complex containing Parp1, Parp2, TP2 and HSPA2. Exp Cell Res 315, 2824-2834.

Raghavan, S.C., and Lieber, M.R. (2004). Chromosomal Translocations and Non-B DNA Structures in the Human Genome. Cell cycle 3, 760-766.

Rass, E., Grabarz, A., Plo, I., Gautier, J., Bertrand, P., and Lopez, B.S. (2009). Role of Mre11 in chromosomal nonhomologous end joining in mammalian cells. Nature structural molecular biology 16, 819-824.

Rathke, C., Baarends, W.M., Jayaramaiah-Raja, S., Bartkuhn, M., Renkawitz, R., and Renkawitz-Pohl, R. (2007). Transition from a nucleosome-based to a protaminebased chromatin configuration during spermiogenesis in Drosophila. J Cell Sci 120, 1689-1700.

Rato, L., Socorro, S., Cavaco, J.E.B., and Oliveira, P.F. (2010). Tubular fluid secretion in the seminiferous epithelium: ion transporters and aquaporins in Sertoli cells. The Journal of membrane biology 236, 215-224.

Robertson, A.B., Klungland, A., Rognes, T., and Leiros, I. (2009). DNA repair in mammalian cells: Base excision repair: the long and short of it. Cellular and molecular life sciences 66, 981-993.

Roca, J., and Mezquita, C. (1989). DNA topoisomerase II activity in nonreplicating, transcriptionally inactive, chicken late spermatids. Embo J 8, 1855-1860. 
Rogakou, E.P., Boon, C., Redon, C., and Bonner, W.M. (1999). Megabase chromatin domains involved in DNA double-strand breaks in vivo. The Journal of cell biology 146, 905916.

Rybar, R., Markova, P., Veznik, Z., Faldikova, L., Kunetkova, M., Zajicova, A., Kopecka, V., and Rubes, J. (2009). Sperm chromatin integrity in young men with no experiences of infertility and men from idiopathic infertility couples. Andrologia 41, 141-149.

Sakkas, D., Mariethoz, E., Manicardi, G., Bizzaro, D., Bianchi, P.G., and Bianchi, U. (1999). Origin of DNA damage in ejaculated human spermatozoa. Rev Reprod 4, 31-37.

Sakkas, D., Moffatt, O., Manicardi, G., Mariethoz, E., Tarozzi, N., and Bizzaro, D. (2002). Nature of DNA damage in ejaculated human spermatozoa and the possible involvement of apoptosis. Biol Reprod 66, 1061-1067.

Scherthan, H., Jerratsch, M., Dhar, S., Wang, Y., Goff, S., and Pandita, T. (2000). Meiotic telomere distribution and Sertoli cell nuclear architecture are altered in Atm- and Atm-p53-deficient mice. Mol Cell Biol 20, 7773-7783.

Schultz, N., Hamra, F.K., and Garbers, D.L. (2003). A multitude of genes expressed solely in meiotic or postmeiotic spermatogenic cells offers a myriad of contraceptive targets. Proceedings of the National Academy of Sciences of the United States of America 100, 12201-12206.

Setchell, B.P. (1969). Do Sertoli cells secrete fluid into the seminiferous tubules? J Reprod Fertil 19, 391-392.

Setchell, B.P. (1998). The Parkes Lecture. Heat and the testis. J Reprod Fertil 114, 179-194.

Shaman, J., Prisztoka, R., and Ward, W. (2006). Topoisomerase IIB and an extracellular nuclease interact to digest sperm DNA in an apoptotic-like manner. Biol Reprod 75, 741-748.

Shannon, M. (1999). Characterization of the Mouse Xpf DNA Repair Gene and Differential Expression during Spermatogenesis. Genomics 62, 427-435.

Shrivastav, M., de Haro, L.P., and Nickoloff, J.A. (2008). Regulation of DNA double-strand break repair pathway choice. Cell research 18, 134-147.

Spano, M., Bonde, J.P., Hjøllund, H.I., Kolstad, H.A., Cordelli, E., and Leter, G. (2000). Sperm chromatin damage impairs human fertility. The Danish First Pregnancy Planner Study Team. Fertility and sterility 73, 43-50.

Stevanin, G., Giunti, P., David, G., and Belal, S. (1998). De novo expansion of intermediate alleles in spinocerebellar ataxia 7. Human molecular ....

Tanphaichitr, N., Sobhon, P., Taluppeth, N., and Chalermisarachai, P. (1978). Basic nuclear proteins in testicular cells and ejaculated spermatozoa in man. Exp Cell Res 117, 347-356.

Thomas, N.S., Durkie, M., Van Zyl, B., Sanford, R., Potts, G., Youings, S., Dennis, N., and Jacobs, P. (2006). Parental and chromosomal origin of unbalanced de novo structural chromosome abnormalities in man. Hum Genet 119, 444-450.

Tóth, G., Gáspári, Z., and Jurka, J. (2000). Microsatellites in different eukaryotic genomes: survey and analysis. Genome research 10, 967-981.

Turley, H., Comley, M., Houlbrook, S., Nozaki, N., Kikuchi, A., Hickson, I., Gatter, K., and Harris, A. (1997). The distribution and expression of the two isoforms of DNA topoisomerase II in normal and neoplastic human tissues. Br J Cancer 75, 1340-1346. 
van der Heijden, G., Derijck, A., Ramos, L., Giele, M., van der Vlag, J., and de Boer, P. (2006). Transmission of modified nucleosomes from the mouse male germline to the zygote and subsequent remodeling of paternal chromatin. Dev Biol 298, 458-469.

Venkatesh, S., Kumar, R., Deka, D., Deecaraman, M., and Dada, R. (2011). Analysis of sperm nuclear protein gene polymorphisms and DNA integrity in infertile men. Systems Biology in Reproductive Medicine.

Vogl, A.W., Vaid, K.S., and Guttman, J.A. (2008). The Sertoli cell cytoskeleton. Adv Exp Med Biol 636, 186-211.

Walter, C., Intano, G., McCarrey, J., McMahan, C., and Walter, R. (1998). Mutation frequency declines during spermatogenesis in young mice but increases in old mice. Proc Natl Acad Sci USA 95, 10015-10019.

Ward, W.S. (1993). Deoxyribonucleic acid loop domain tertiary structure in mammalian spermatozoa. Biol Reprod 48, 1193-1201.

Watanabe, S., Tanaka, A., Fujii, S., Mizunuma, H., Fukui, A., Fukuhara, R., Nakamura, R., Yamada, K., Tanaka, I., Awata, S., et al. (2011). An investigation of the potential effect of vacuoles in human sperm on DNA damage using a chromosome assay and the TUNEL assay. Human Reproduction.

Weng, S., Taylor, S., Morshedi, M., Schuffner, A., Duran, E., Beebe, S., and Oehninger, S. (2002). Caspase activity and apoptotic markers in ejaculated human sperm. Mol Hum Reprod 8, 984-991.

West, S.C. (2003). Molecular views of recombination proteins and their control. Nature reviews Molecular cell biology 4, 435-445.

Wojtczak, A., Popłońska, K., and Kwiatkowska, M. (2008). Phosphorylation of H2AX histone as indirect evidence for double-stranded DNA breaks related to the exchange of nuclear proteins and chromatin remodeling in Chara vulgaris spermiogenesis. Protoplasma 233, 263-267.

Wold, M.S. (1997). Replication protein A: a heterotrimeric, single-stranded DNA-binding protein required for eukaryotic DNA metabolism. Annual review of biochemistry 66, 61-92.

Xie, A., Kwok, A., and Scully, R. (2009). Role of mammalian Mre11 in classical and alternative nonhomologous end joining. Nature structural \& molecular biology 16, 814-818.

Yan, W., Ma, L., Burns, K., and Matzuk, M. (2003). HILS1 is a spermatid-specific linker histone H1-like protein implicated in chromatin remodeling during mammalian spermiogenesis. Proc Natl Acad Sci USA 100, 10546-10551.

Yen, P. (1998). A Long-Range Restriction Map of Deletion Interval 6 of the Human Y Chromosome: A Region Frequently Deleted in Azoospermic Males. Genomics 54, 5-12.

Zaalishvili, G.T., Tsetskhladze, Z.R., Margiani, D.O., Gabriadze, I.I., and Zaalishvili, T.M. (2005). ADP-ribosylation intensifies cleavage of DNA loops in the nuclear matrix. Mol Biol (Mosk) 39, 317-320.

Zalenskaya, I.A., Bradbury, E.M., and Zalensky, A.O. (2000). Chromatin structure of telomere domain in human sperm. Biochem Biophys Res Commun 279, 213-218.

Zini, A. (2011). Are sperm chromatin and DNA defects relevant in the clinic? Systems Biology in Reproductive Medicine 57, 78-85. 
Zini, A., Boman, J.M., Belzile, E., and Ciampi, A. (2008). Sperm DNA damage is associated with an increased risk of pregnancy loss after IVF and ICSI: systematic review and meta-analysis. Human Reproduction 23, 2663-2668.

Zühlke, C., Rless, O., Bockel, B., Lange, H., and Thies, U. (1993). Mitotic stability and meiotic variability of the (CAG) nrepeat in the Huntington disease gene. Human Molecular Genetics 2, 2063-2067. 


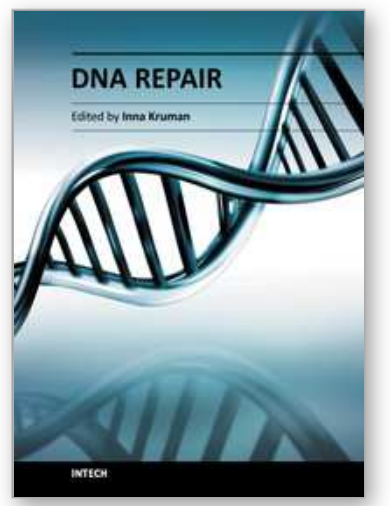

\author{
DNA Repair \\ Edited by Dr. Inna Kruman
}

ISBN 978-953-307-697-3

Hard cover, 636 pages

Publisher InTech

Published online 07, November, 2011

Published in print edition November, 2011

The book consists of 31 chapters, divided into six parts. Each chapter is written by one or several experts in the corresponding area. The scope of the book varies from the DNA damage response and DNA repair mechanisms to evolutionary aspects of DNA repair, providing a snapshot of current understanding of the DNA repair processes. A collection of articles presented by active and laboratory-based investigators provides a clear understanding of the recent advances in the field of DNA repair.

\title{
How to reference
}

In order to correctly reference this scholarly work, feel free to copy and paste the following:

Frédéric Leduc, Geneviève Acteau, Marie-Chantal Grégoire, Olivier Simard, Jessica Leroux, Audrey CarrierLeclerc, Mélina Arguin and Guylain Boissonneault (2011). Post-Meiotic DNA Damage and Response in Male Germ Cells, DNA Repair, Dr. Inna Kruman (Ed.), ISBN: 978-953-307-697-3, InTech, Available from: http://www.intechopen.com/books/dna-repair/post-meiotic-dna-damage-and-response-in-male-germ-cells

\section{INTECH}

open science | open minds

\section{InTech Europe}

University Campus STeP Ri

Slavka Krautzeka 83/A

51000 Rijeka, Croatia

Phone: +385 (51) 770447

Fax: +385 (51) 686166

www.intechopen.com

\section{InTech China}

Unit 405, Office Block, Hotel Equatorial Shanghai

No.65, Yan An Road (West), Shanghai, 200040, China 中国上海市延安西路65号上海国际贵都大饭店办公楼 405 单元

Phone: +86-21-62489820

Fax: $+86-21-62489821$ 
(C) 2011 The Author(s). Licensee IntechOpen. This is an open access article distributed under the terms of the Creative Commons Attribution 3.0 License, which permits unrestricted use, distribution, and reproduction in any medium, provided the original work is properly cited. 